\title{
Evaluation of Available Resources for Early Childhood Education Programme in Adaklu District, Volta-Region, Ghana
}

\author{
Y. Dzakadzie and S. Agbayisah
}

\section{ABSTRACT}

The study sought to evaluate the available resources for Early Childhood Education (ECE) programme delivery in Adaklu district, Volta-region, Ghana. Two research objectives guided the study, and they were to examine the availability of instructional resources for ECE programme delivery and to ascertain the available infrastructure for the provision of ECE programme in the district. Descriptive survey research design was used for the study. The instrument for data collection was a selfconstructed 4-point Likert type scale questionnaire. The study covered 200 ECE teachers within 40 basic schools in the district. Stratified random sampling technique was used to obtain sample for the study. Descriptive statistics (mean and standard deviation) and inferential statistics (population t-test) were used to analyze data obtained with respect to each research question. It was evidenced from the study that essential instructional and infrastructural resources necessary for the delivery of quality Early Childhood Education were absent and in limited supply in the schools within the Adaklu district. The study concludes therefore that the provision of ECE in the Adaklu district within the Volta Region of Ghana is not of high quality. It is recommended among others that the head teachers, the coordinator for Early Childhood Education and the director of education in the Adaklu district should identify other sources of funding like appealing to NGOs, prominent individuals and philanthropists in and out of the district to help provide instructional resources for the education of children in the schools within the district. This would help minimize the inadequacy and total lack of teaching and learning materials within the schools in the district.

Keywords: Evaluation, Infrastructure, Instructional Resources, Programme

Published Online: February 8, 2022

ISSN: $2736-4534$

DOI : 10.24018/ejedu.2022.3.1.250

\section{Y. Dzakadzie*}

Faculty of Educational Studies, University of Education, Winneba, Ghana.

(ydzakadzie@ uew.edu.gh)

S. Agbayisah

Agogo Presbyterian Women College of

Education, Asante Akyem-Agogo, Ghana.

(seth.agbayisah ${ }^{\circledR}$ stu.ucc.edu.gh)

*Corresponding Author

\section{INTRODUCTION}

Paramount to the delivery of Quality Early Childhood Education (QECE) is the availability of instructional and infrastructural resources. The availability of these resources at Early Childhood Education (ECE) centres is critical the childs' learning and development because, these resources help the caregiver/teacher to support and effectively implement the curriculum. Chukwbikem (2013) noted that, the quantity and quality of resources available in a school for any educational programme, determine the schools' system capacity for the implementation of the type of educational programme. Obanya (2003) asserted that, instructional materials are didactic material things which are supposed to make learning and teaching possible while Abdullahi (2003) described teaching and learning materials as materials or tools locally made or imported that could make tremendous improvement on a lesson if intelligently used. If the teacher of Early Childhood Education centre hope to impart change and improvement in the performance of learners, there must be adequate and appropriate resources in terms of structures and teaching-learning resources (Kimani, 1990).

Ayot and Patel (2006) submitted that, teaching resources are used to increase learning, to generate more interest and to create a situation where the learners would fully engage in classroom activities. Tarimo (2013) on the determinants of primary school teachers' commitment to teaching in Kenya reported that slow process of ordering and supplying instructional materials was the number one factor or determinant of their non- commitment in Kenya. This finding reported by Tarimo (2013) shows the importance of teaching and learning materials in the teaching and learning process. It is necessary for teachers therefore to have sufficient indoor and outdoor resources in order to engage in effective teaching and learning of children. Ng'asike (2004) commended that, pre-primary school teachers tend to actively engage materials in their teaching when the teaching and learning environment is conducive. Teacher's role is therefore to create an environment that invites learners to observe, to be active, make choices and to experiment (Judy, 2001).

Saunders as cited in Santrock (2014) stressing the importance of using variety of instructional materials 
indicated that, people receive experience through all the five senses (touch, taste, smell, hearing and sight). He added that, if teachers can appeal to more than one sense at a time, their message is likely to be understood and accepted more permanently. Santrock further explained that, different materials appeal to different people, therefore when planning lessons or work, teachers must not concentrate on memory work alone, but on hearing, seeing, touching, doing and making (p.271). To ensure quality instructional delivery for the benefit of both teacher and learner, early grade education requires the appropriate use of a judicious mix of both print, audio, visual, audio-visual and other materials. These materials include but not limited to textbooks, journals, magazines, periodicals, wall charts, posters, pictures, maps, globes, filmstrips, slides, projectors, graphs, radio, taperecorders, televisions, flash cards, chalk, marker among others (Adebule, 2008; Chukwu, Eze, \& Agada, 2016).

Infrastructural facilities on the other hand are very essential in the delivery of Quality Early Childhood Education. Shively (2017) opines that learning objectives to be achieved need to be supported by adequate facilities and infrastructure, safe and pleasant learning environment situation. Facilities and infrastructure such as buildings, classrooms, tables, chairs, yard, garden or school park are all vital in effective delivery and implementation of Early Childhood Education policies (Gallagher \& Clifford, 2000). Educational infrastructural facilities are one of the important resources in supporting the implementation of Early Childhood Education policies and the learning process in Early Childhood Education centres. The success of education programs in schools is therefore, strongly influenced by the conditions of educational facilities and infrastructure owned by schools and by optimizing their management and utilization (Khikmah \& Mukminin, 2017). Good infrastructural facilities are expected to create clean, neat and beautiful schools that create pleasant conditions for both teachers and students to be in school (Cassey, 2005). In addition, Cassey, added that, it is also expected that the availability and optimal usage of adequate learning tools or facilities are essential for the benefit of childrens' education and teaching process.

Despite the important roles instructional and infrastructural resources play in the development and learning of children, several research indicated that, these resources are mostly not found or available in many early childhood schools especially in the early grade section of public primary schools that belong to the government (Okewole, et al., 2015; Osho, et al., 2013). For instance, Abdulai (2014) revealed that inadequacy of teaching and learning materials was identified as a major challenge associated with early childhood educational practices. Twum (2016) similarly reported that, there was an inadequacy of teaching and learning materials such as picture cards, number cards, drawing cards, sand tray, picture slates and alphabetic cards and general infrastructural problems among pre-schools in the Shama District which impedes the smooth delivery of pre-school education in the district. Also, Education International (2010) submitted that the challenges preschools especially in the rural areas face were inadequate and inappropriate teaching and learning materials.

Little however have been known about the nature and availability of educational resources for the delivery of quality Early Childhood Education in the Adaklu district.
Again, most of the earlier studies which indicate inadequacy of these resources in some parts of the country have been conducted for some now. The question therefore is, are there adequate availability of resources towards the delivery of quality early childhood education in Adaklu? Does the availability or unavailability of these resources influence quality delivery of Early Childhood Education programme in the study area? Answers to these mind-bending questions are essential in ensuring quality provision of ECE programme, however, these answers are not readily documented in current literature. This study was therefore conducted to evaluate the available resources for Early Childhood Education programme in Adaklu district, Volta-region, Ghana.

\section{A. Research Objectives}

The study sought to:

1. Examine the availability of instructional resources for Early Childhood Education programme delivery in the district.

2. Ascertain the availability of infrastructure for the provision of Early Childhood Education programme in the district.

\section{B. Research Questions}

The study was guided by the following questions:

1. What are the available instructional resources for Quality Early Childhood Education programme delivery in the district?

2. What is the available infrastructure for the delivery of Quality Early Childhood Education programme in the district?

\section{Methodology}

Descriptive survey research design was adopted and used for the study. Measurement of variables of interest occurred at a time and there was no attempt to manipulate any of the variables measured in this study. The study targeted all Basic schools and all the ECE teachers. The accessible population was however made up of 40 Basic Schools from the 8 educational circuits and 200 Early Childhood Education teachers from the selected Basic Schools. Stratified random sampling technique was used to sample the schools and all ECE teachers in a sampled school was used for the study. This implies that the schools were the unit of sampling $[(40 \times 5=$ 200)].

The instrument of data collection was a self-constructed 4point Likert type scale questionnaire. There were two sections on the questionnaire. Items on section A were used to elicit data on the available instructional resources and section $B$ elicit response on the available infrastructure for QECE delivery. There were sixteen (16) items on section A and eight (8) items on section B of the questionnaire. The rating format ranges from "strongly agree" (4) to "strongly disagree" (1). Cronbach's alpha coefficient was used to determine the consistency of the instrument. The result of the reliability alpha coefficient for the instrument was approximately .755 indicating that instrument met the threshold to be used for the study (Dörnyei \& Taguchi, 2010). Descriptive statistics (mean and standard deviation) were used to analyze data obtained with respect to each research question. Again, population t-test or one sample t-test of one sample mean was 
used to further test the results.

\section{RESULTS}

\section{A. Available Instructional Resources for Quality Early Childhood Education Delivery.}

The first research question "What are the available instructional resources for Quality Early Childhood Education programme delivery in the district?" sought to examine the available instructional or teaching and learning resources in the various Early Childhood Education centres within the Adaklu district. It was necessary to examine the availability of these resources because they are very critical to the successful implementation of QECE programs and its curriculum. Tassoni (2002) stated that, as part of the smooth running of any preschool setting, it is important that there is a constant, adequate and regular supply of equipment and materials for effective teaching and learning. Data gathered in relation to this research question were analyzed using mean and standard deviation presented in Table I and population T or one sample T-test of one sample mean presented Table II.

Table I presents the results of available instructional or teaching and learning resources within schools in the Adaklu district. An average or mean of means scores of 2.07 with a corresponding standard deviation of 0.462 was computed for the sixteen (16) items (statements) representing instructional resources within schools in the district. Associating the mean of means score of 2.07 to the individual means of the items (statements), it could be observed that the means for the statements relating to available "educational games such as bingo" (Mean = 1.98; SD = 1.037), "seesaw(s)" (Mean = 1.45; $\mathrm{SD}=1.065)$, "marry-go-round(s)" $($ Mean = 1.29; $\mathrm{SD}=$ $0.882)$, "swing(s)" (Mean $=1.24$; $\mathrm{SD}=0.816)$, "marbles" $($ Mean $=2.04 ; \mathrm{SD}=1.430)$, "counting blocks" $($ Mean = 1.30; $\mathrm{SD}=0.902)$, "cuisenaire rods" $($ Mean $=1.26 ; \mathrm{SD}=0.839)$, "toys" (Mean = 1.69; SD = 1.266) and "puzzles for indoor activities" $($ Mean $=1.83 ; \mathrm{SD}=1.343)$ respectively were lower or lesser than the calculated mean of means of 2.07. These results as provided in Table I suggest that the teachers strongly disagreed homogeneously to these statements which indicate that, these resources are absent or not available in schools within the Adaklu district.

TABLE I: RESULTS OF AVAILABLE INSTRUCTIONAL RESOURCES

\begin{tabular}{lcc}
\hline \hline Statements & Mean & Std. Dev. \\
\hline Story and picture books for teaching. & 2.38 & 0.965 \\
Flashcards for teaching and learning. & 2.51 & 0.845 \\
Clay and sand for modeling activities & 3.07 & 0.916 \\
Visual aids like posters for teaching. & 2.59 & 1.013 \\
Alphabets cards for teaching and learning & 2.91 & 0.970 \\
Educational games for teaching. & 1.98 & 1.037 \\
Seesaw(s) for outdoor activities. & 1.45 & 1.065 \\
Marry-go-round(s) for outdoor activities. & 1.29 & 0.882 \\
Swing(s) for outdoor activities. & 1.24 & 0.816 \\
Skipping rope(s) for outdoor activities. & 2.21 & 1.476 \\
Marbles for indoor activities. & 2.04 & 1.430 \\
Counting blocks for indoor activities. & 1.30 & 0.902 \\
Cuisenaire rods for indoor activities. & 1.26 & 0.839 \\
Toys for indoor activities. & 1.69 & 1.266 \\
Puzzles for indoor activities. & 1.83 & 1.343 \\
Bottle tops for indoor activities. & 3.42 & 1.170 \\
\hline Mean of Means and Std. Dev. & 2.07 & .462 \\
\hline \hline Std Dev. Standard Deviation & &
\end{tabular}

The results further suggest that there was absence of story and picture books $($ Mean $=2.38 ; \mathrm{SD}=0.965)$ and skipping rope(s) for outdoor activities (Mean $=2.21$; $\mathrm{SD}=1.476$ ). There was however, much variation in their responses where some teachers indicated that these materials were available. Notwithstanding the absence of these resources, data presented in Table I shows that there were flashcards such as sight words $($ Mean $=2.51 ; \mathrm{SD}=0.845)$, clay and sand for modeling activities (Mean $=3.07$; $\mathrm{SD}=.916$ ), visual aids such as wall pictures, posters $($ Mean $=2.59$; $\mathrm{SD}=1.013$ ), bottle tops $($ Mean $=3.42 ; \mathrm{SD}=1.170)$ and alphabets cards (Mean $=2.9 ; \mathrm{SD}=0.970$ ) for teaching and learning within schools in the district.

TABLE II: RESUltS OF POPULATION T-TeST ANALySIS OF AVAILABLE INSTRUCTIONAL RESOURCES.

\begin{tabular}{lcccccc}
\hline \hline & Total & $\begin{array}{c}\text { Sample } \\
\text { Mean }\end{array}$ & $\begin{array}{c}\text { Sample } \\
\text { Std. Dev. }\end{array}$ & $\begin{array}{c}\text { Ref. } \\
\text { Mean }\end{array}$ & t-value & Sig \\
\hline $\begin{array}{l}\text { Total available } \\
\begin{array}{l}\text { Instructional } \\
\text { Resources }\end{array}\end{array}$ & 200 & 2.07 & 0.462 & 2.5 & -13.088 & 0.000 \\
\hline $\mathrm{p}<0.05 ; \mathrm{df}=199 ;$ Mean Difference $=-.42750 ;$ Ref. = Reference Mean
\end{tabular}

Population T-test analysis or one sample T-test of one sample mean was further conducted to determine the available instructional materials within schools in the Adaklu district. The test was conducted at an alpha level of .05 and the result presented in Table II. Using the population T-test, a sample mean was compared with a reference mean score or population mean score of 2.5. The reference mean score was obtained by finding the average of the scores attached to the four responses to the items by the number of items. The reference mean score was also confirmed by using mid-point on the test variables (Green et al., 2000). Thus, reference mean is; $1 / 4(4+3+2+1)=2.5$ Or $1 / 2(3+2)=2.5$.

The result presented in Table II shows that the sample mean score for the total population with respect to the available instructional resources $($ Mean $=2.07$; $\mathrm{SD}=0.462$ ) was lower or less than the reference mean score of (2.5). Similarly, the calculated t-value or absolute value (-13.088) was less than the critical t-value of 1.96 at 0.05 level of significance with 199 degrees of freedom. The result also shows a significant level of 0.000 which is less than the alpha level of 0.05 . The result as presented in Table II therefore means that, there is the absence and inadequacy of instructional or teaching and learning materials.

\section{B. Available Infrastructure for the Delivery of Early Childhood Education in Adaklu District.}

Research question two "What are the available infrastructure for the delivery of Quality Early Childhood Education programme in the district?" sought to ascertain the availability of infrastructural facilities for the delivery of Early Childhood Education within the Adaklu district. AzziLessing (2009) indicates that adequate and proper infrastructure is crucial to provide high quality education to children because infrastructure, within a complex system, serves as a foundation for the rest of activities in the school. It was therefore paramount to determine the availability and status of infrastructural facilities of the schools within the Adaklu district. Data were analyzed using mean and standard deviation presented in Table III and population $\mathrm{T}$ or one sample T-test of one sample mean presented Table IV. 
TABLE III: RESULTS OF AVAILABLE INFRASTRUCTURAL FACILITIES

\begin{tabular}{|c|c|c|}
\hline Statements & Mean & Std. Dev. \\
\hline $\begin{array}{l}\text { Adequate indoor space for teaching and learning } \\
\text { activities }\end{array}$ & 2.98 & .985 \\
\hline Adequate space for outdoor games and activities. & 3.42 & .675 \\
\hline Toilet and urinal facilities for children & 3.22 & .749 \\
\hline Store rooms for the storage of children materials & 2.37 & 1.029 \\
\hline Kitchen for preparing food for the children & 1.90 & 1.115 \\
\hline Spacious room for children's rest & 1.66 & .858 \\
\hline Buildings for ECE delivery in good condition & 2.11 & .976 \\
\hline $\begin{array}{l}\text { Waiting room for parents and visitors to relax } \\
\text { whiles waiting for the teachers or their children }\end{array}$ & 1.33 & .665 \\
\hline Mean of Means and Standard Deviation & 2.48 & .427 \\
\hline
\end{tabular}

Table III presents summary of the teachers' responses with respect to the available infrastructural facilities in the Adaklu district. The table depicts that there is a conducive and large space for indoor and outdoor activities in the schools within the district. This was evidenced from the table as the teachers agreed to the statements indicating adequate indoor (Mean = 2.98; $\mathrm{SD}=.985)$ and outdoor $($ Mean $=3.42 ; \mathrm{SD}=0.675)$ spaces for activities in and out of the classroom setting respectively. Again, the teachers were in agreement that there were toilet and urinal facilities for children (Mean $=3.22$; SD $=.749$ ). Regardless of the availability of these infrastructural facilities, Table III reveals the absence of store rooms (Mean $=2.37 ; \mathrm{SD}=1.029)$, spacious room for children's rest (Mean $=1.66 ; \mathrm{SD}=0.858$ ) and waiting room for parents and visitors to relax whiles waiting for the teachers or their children (Mean $=1.33 ; \mathrm{SD}=0.665)$. Also, there is no kitchen for preparing food for the children $($ Mean $=1.90 ; \mathrm{SD}=1.115)$ and the available buildings for Early Childhood Education delivery are not in good condition $($ Mean $=2.11 ; \mathrm{SD}=0.976)$.

TABLE IV: RESUltS OF POPULATION T-TEST ANALYSIS FOR AVAILABLE INFRASTRUCTURE.

\begin{tabular}{lcccccc}
\hline \hline & Total & $\begin{array}{c}\text { Sample } \\
\text { Mean }\end{array}$ & $\begin{array}{c}\text { Sample } \\
\text { Std. Dev. }\end{array}$ & $\begin{array}{c}\text { Ref. } \\
\text { Mean }\end{array}$ & t-value & Sig \\
\hline $\begin{array}{l}\text { Total available } \\
\text { infrastructural } \\
\text { Resources }\end{array}$ & 200 & 2.48 & 0.427 & 2.5 & -0.808 & 0.420 \\
\hline \hline
\end{tabular}

p< 0.05; df =199; Mean Difference = -0.42750; Ref. = Reference Mean

Population T-test analysis or one sample T-test of one sample mean was further conducted to determine the available infrastructure for ECE delivery in the Adaklu district. The test was conducted at the alpha level of 0.05 and the result presented in Table IV. Using the population T-test, the sample mean was compared with a reference mean score of 2.5 .

The result presented in Table IV indicates that the sample mean score of the total population in relation to the available infrastructure for ECE delivery $($ Mean $=2.48 ; \mathrm{SD}=0.427$ ) was less than the reference mean score of (2.5). Similarly, the calculated t-value or absolute value $(-0.808)$ was less than the critical t-value of 1.96 at 0.05 level of significance with 199 degrees of freedom. This result implies that although there are some facilities available in some schools within the district, there is general inadequacy of infrastructural facilities for the delivery of Early Childhood Education in the Adaklu district in the Volta Region of Ghana.

\section{DISCUSSION}

Data analyzed with respect to the first research question suggests that most of the teaching and learning resources deemed vital and necessary for ECE delivery were not available in the schools within the Adaklu district. Notable among them includes story and picture books, educational games such as bingo, seesaw, marry-go-round, swings, skipping ropes, marbles, blocks, cuisenaire rods, toys and puzzles among others. Although there were some available materials such as alphabet card, clay and sand for modelling, flash cards as well as bottle tops for instructional purpose, there was much variation among the responses of the teachers in relation to these materials. Thus, there was no cohesion and homogeneity among the responses of the teachers in relations to those teaching and learning materials that exist in the schools within the district. This heterogeneity or variation among the responses of the teachers with regards to the availability of these teaching and learning materials indicated that, although these materials were available in schools within the district, they may not be evenly distributed among the various schools in the district and therefore, some schools in the district have them whiles others do not have them. Also, the variation in the responses could be that, these materials were available, however, they may be inadequate for the schools in the Adaklu district. This finding was similar to a submission made by Abdulai (2014) which indicated that inadequacy of teaching and learning materials was identified as a major challenge associated with early childhood educational practices. Similarly, Education International (2010) reported that the challenges preschools especially in the rural areas face were inadequate and inappropriate teaching and learning materials.

Analysis of research question two further indicates that, although there was adequate space for indoor and outdoor activities as well as the presence of toilet and urinal facilities in schools within district; there were absence of vital infrastructural facilities such as store rooms for the storage, kitchens, spacious room for children's rest as well as waiting room for parents and visitors to relax whiles waiting for the teachers or their children. This finding agrees with a report submitted by Twum (2016) which stated that there was lack of quality infrastructure among pre-schools in the Shama District, Ghana which negatively affected the smooth and successful delivery and implementation of Pre-school education. Similarly, Oppong Frimpong (2019) reported that there were general infrastructural problems in the form of inappropriate furniture, un-resourced learning centres among others in the schools within the Ga West Municipality.

\section{CONCLUSIONS}

It was evidenced from the study that essential instructional and infrastructural resources deemed necessary for the delivery of quality Early Childhood Education were absent and in limited supply in the schools within the Adaklu district. Giving the fact that the provision of quality Early Childhood Education depends largely on the quantity and the quality of instructional and infrastructural resources available, the study concludes that the provision of Early Childhood Education in the Adaklu district within the Volta Region of Ghana is not of high quality. In other words, the smooth and successful implementation or delivery of quality Early Childhood Education in the Adaklu district is hindered or impeded by the inadequacy and absence of essential instructional and 
infrastructural resources.

\section{RECOMMENDATIONS}

Based on the findings, it is recommended that the head teachers, the coordinator for Early Childhood Education and the director of education in the Adaklu district must and should identify other sources of funding like appealing to NGOs, prominent individuals and philanthropists in the district to help provide instructional resources for the education of children in the schools within the district. This will help minimize the inadequacy and total lack of teaching and learning materials within the schools in the district. Also, the District Chief Executive (DCE) and the District Educational Director should appeal and lobby through the Member of Parliament (MP) to the central government to help provide infrastructural facilities for the schools in the district to improve the smooth delivery of Early Childhood Education programme in the district.

\section{FUNDING}

There was no funding from an agency

\section{CONFLICT OF INTEREST}

The researchers declared no conflict of interest in the conduct of the study.

\section{REFERENCES}

Abdulai, A. (2014). Challenges facing early childhood education in Ghana: What do stakeholders say. Advances in Social Sciences Research Journal, 1(3), 11-24.

Abdullahi, S. M. (2003). Evaluation of vocational technical training programs in northern Nigeria prisons. Journal of League of Researchers in Nigeria. (JOLORN), 8(1).

Adebule, D. I. (2008). Availability of instructional materials at the basic education level in Enugu Educational Zone of Enugu State, Nigeria. Journal of Curriculum Studies. (Special Edition 2008), 282, 291.

Ayot, H. O., \& Patel, M. M. (2006). Instructional methods. Nairobi: Educational Research and Publications LTD.

Azzi-Lessing, L. (2009). Quality support infrastructure in early childhood: Still (Mostly) Missing. Early Childhood Research \& Practice, 11(1), 1-10.

Cassey, S. (2005). Establishing standards for social infrastructure. Ipswich, Australia: UQ Boiler house, Community Engagement Centre.

Chukwbikem, P. E. I (2013). Resources for early childhood education. Mediterranean Journal of Social Sciences, 4(8), 161-172.

Chukwu, L. C., Eze, T. A., \& Agada, F. C. (2016). Availability of instructional materials at the basic education level in Enugu Educational Zone of Enugu State, Nigeria. Journal of Education and Practice, 7(12), 7-10.

Dornyei, Z., \& Taguchi, T. (2010). Questionnaires in Second Language Research: Construction, Administration and Processing (2nd ed.). New York: Routledge.
Education International (2010). Early childhood education: A global scenario. Retrieved from http://www.ei-ie.org

Gallagher, J. J., \& Clifford, R. M. (2000). The missing support infrastructure in early childhood. Early Childhood Research \& Practice, 2(1), 1-8.

Judy, M. P. (2001). Considering pedagogical content knowledge in the context of research on teaching: An example from technology. Hamilton, New Zealand: Wilf Malcolm Institute of Educational Research, University of Waikato.

Khikmah, A., \& Mukminin, A. (2017). The readiness of the early childhood education institution establishment in terms of the availability of facilities and infrastructure; A Case Study of playgroup Aisyiyah, Kabupaten Kudus. BELIA: Early Childhood Education Papers, 6(1), 1-5.

Kimani, P. (1990). Effects of low vision in teaching mathematic to learners with low knowledge-based approach. Technische: Universiteit Eindhoven Press.

Ng'asike, J. T. (2004). Teachers' use of play as medium for bridging pre-school children's mathematical experiences. A study of Kasarani Division, Nairobi, Kenya [Unpublished MEd Thesis]. Kenyatta University.

Obanya, P. (2003, June). Major challenges to the development of secondary education in Nigeria. In First Regional Conference on Secondary Education in Africa (SEIA), Kampala, Uganda.

Okewole, J. O., Iluezi-Ogbedu, V. A., \& Osinowo O. A. (2015). An evaluation of the implementation of early childhood education curriculum in Osun State. Journal of Education and Practice, 6(4), 48-54.

Oppong Frimpong, S. (2019). The classroom physical environment as a "third teacher" for an early childhood education provision in the Ga-West Municipality of Ghana. PEOPLE: International Journal of Social Sciences, 4(3), 1339-1360.

Osho, L. O., Aliyu, N., Okolie, O., \& Onifade, O. (2013). Implementation of early childhood education: A case study in Nigeria. Universal Journal of Educational Research, 2(2), 119-125.

Santrock, J. W. (2014). An investigation on the utilization of instructional materials in pre-primary schools in Morogoro municipal council [Unpublished Doctoral dissertation]. The Open University of Tanzania, Tanzania

Shively, G. E. (2017). Infrastructure mitigates the sensitivity of child growth to local agriculture and rainfall in Nepal and Uganda. Proceedings of the National Academy of Sciences, 114(5), 903-908.

Tarimo, J. (2013). Teachers' use of play as a teaching strategy in pre-primary schools in Mwanga district, Kilimanjaro region, Tanzania. [Unpublished M. Ed. Thesis]. Kenyatta University, Kenya.

Tassoni, P. (2002). Planning for the foundation stage: ideas for themes and activities. London: Heinemann Educational Publishers.

Twum, L. O. (2016). Pre-school teacher's perception of the challenges facing pre-school education in Shama District [Unpublished Doctoral dissertation]. University of Cape Coast. 